\title{
PELANGGARAN ETIK PENYELENGGARA PEMILU KABUPATEN ROKAN HULU TAHUN 2015
}

\author{
Oleh: Adrian Faridhi \\ Dosen Fakultas Hukum Universitas Lancang Kuning \\ Alamat Kantor Jl. Yos Sudarso Km 8 Rumbai \\ Email: adrian.faridhi86@gmail.com
}

\begin{abstract}
Abstrak
Posisi yang strategis sebagai penyelenggara Pemilu, memiliki potensi penyimpangan tingkah dan laku sebagai penyelenggara, seperti pernah terjadi di Kabupaten Rokan Hulu pada tahun 2015. Terkait dengan isu pelanggaran tersebut maka permasalahan dalam artikel ini ada 2 (dua): Pertama, bagaimana implementasi Peraturan Bersama KPU, BAWASLU dan DKPP di Kabupaten Rokan Hulu Tahun 2015? Kedua, bagaimana penyelesaian pelanggaran Kode Etik Penyelenggara Pemilu di Kabupaten Rokan Hulu Tahun 2015? Metode penelitian yang digunakan dalam artikel ini merupakan penelitian hukum sosiologis, yakni dengan lebih memfokuskan terhadap persoalan-persoalan yang muncul. Untuk itu, penulis menitikberatkan pembahasan pada ketentuan perundangundangan dan melihat bagaimana hukum dipraktikkan dalam masyarakat. Hasil penelitian ini bahwa implementasi Peraturan Bersama KPU, BAWASLU dan DKPP di Kabupaten Rokan Hulu telah diterapkan pada kasus konkrit berdasarkan Putusan Nomor 111/DKPP-PKE-V/2016 DKPP Pemilu Republik Indonesia yang sebelumnya menerima Pengaduan Nomor 155/V-P/LDKPP/2015, dan diregistrasi pada tanggal 21 Juni 2016 yang disiarkan secara teleconference Kantor BAWASLU Provinsi Riau dengan terlapor (Rahmat Kurniawan, S.E.) Penyelesaian pelanggaran kode etik penyelenggara Pemilu di Kabupaten Rokan Hulu Tahun 2015 yang melibatkan Anggota Komisioner KPU Kabupaten Rokan Hulu Provinsi Riau, merupakan kasus pelanggaran etik yang masuk dalam kategori berat. Putusan DKPP hanya punya menyangkut pelanggaran etik, serta sanksi yang diberikan berupa sanksi etik (untuk pelanggaran berat sanksinya berupa pemberhentian sebagai penyelenggara Pemilu).
\end{abstract}

\begin{abstract}
Strategic position as an organizer of the elections, has the potential deviation behavior and conduct as an organizer, as happened in Rokan Hulu in 2015. Related to the issue of such breach the issues in this article there are 2 (two): First, how the implementation of the Joint Commission Regulation , BAWASLU and DKPP in Rokan Hulu 2015? Second, how the completion of the Election Code violations in Rokan Hulu 2015? The method used in this article is a sociological research, namely by focusing more on the problems that arise. To that end, the author focuses the discussion on the provisions of the legislation and see how the law is practiced in society. The results of this study that the implementation of the Regulation of the Joint Commission, BAWASLU and DKPP in Rokan Hulu has been applied in concrete cases pursuant to Decision No. 111/DKPP-PKE-V/2016 DKPP Elections of the Republic of Indonesia, which had previously received Complaint No. 155/VP/LDKPP/ 2015 and registered on June 21, 2016 which was broadcast by teleconference Office BAWASLU Riau Province with
\end{abstract}


reported (Rahmat Kurniawan, S.E.) Completion code violations election organizers in Rokan Hulu in 2015 involving Members Commissioner Commission Rokan Hulu Riau Province, is a case of breach of ethics which is included in the heavy category. Decision $D K P P$ only had regarding ethics violations, and penalties are given sanction of conduct (for the gross violations of the sanctions in the form of dismissal as election organizers).

\section{Kata kunci: Pelanggaran, Peraturan Bersama, Kode Etik}

\section{Pendahuluan}

Pemilihan Umum (selanjutnya disebut Pemilu) merupakan pesta demokrasi pada suatu negara. Pemilu di Indonesia diselenggarakan satu kali dalam lima tahun. Perioderisasi pemilu di Indonesia merupakan salah satu perwujudan dari kedaulatan rakyat yang mencirikan semangat dari berdemokrasi. Pemilu sebagai mekanisme penyaluran pendapat rakyat secara berkala dilindungi oleh konstitusi disetiap negara yang demokratis. Pasca Amandemen Undang-Undang Dasar Negara Republik Indonesia Tahun 1945 (UUD 1945), pemilihan kepala daerah (gubernur dan wakil gubernur, bupati dan wakil bupati dan walikota dan wakil walikota) dipilih secara langsung oleh rakyat).

Penyelenggaraan Pemilu yang berkualitas, akuntabel dan jujur akan membawa dampak yang positif bagi penyelenggaraan pemerintahan lima tahun ke depan. Pemilu merupakan salah satu sarana politik untuk mewujudkan kehendak rakyat kepada Negara dalam sistem Demokrasi. Rakyat sebagai pemegang kedaulatan berhak menentukan warna dan bentuk pemerintahan serta tujuan yang hendak dicapai, sesuai dengan konstitusi yang berlaku di suatu negara. Rakyat diletakkan pada posisi sentral (government or rule by the people), di mana kekuasaan pemerintahan negara atau keputusan-keputusan politik dilakukan oleh rakyat atau atas kemauan rakyat atau golongan yang memerintah melalui wakil yang dipilih dan akhirnya mempertanggungjawabkan tindakan-tindakannya kepada rakyat. ${ }^{1}$ Menurut Pasal 1 Ayat (2) UUD Tahun 1945 Pasca Amandemen bahwa kedaulatan berada di tangan rakyat dan dilaksanakan menurut Undang-Undang Dasar. Hal inilah yang menjadi dasar bagi penyelenggaraan Pemilu di Indonesia yang mencerminkan semangat demokrasi yang bersumber pada kedaulatan rakyat.

Pelaksanaan Pemilu dijabarkan dalam penyelenggaraan Pemilu Dewan Perwakilan Rakyat (DPR), Pemilu Dewan Perwakilan Rakyat Daerah Provinsi (DPRD Provinsi), Pemilu Dewan Perwakilan Rakyat Daerah Kabupaten/Kota DPRD Kabupaten/ Kota) dan Pemilu Dewan Perwakilan Daerah (Pemilu DPD), Pemilu Presiden dan Wakil Presiden (Pilpres) dan Pemilihan Kepala Daerah (Pilkada Gubernur dan Wakil Gubernur, Bupati dan Wakil Bupati dan Walikota dan Wakil Walikota). Penyelenggara pemilu merupakan bagian terpenting demi sukses dan berkualitasnya hasil dari pemilu tersebut.

Pemilu menjadi tolok ukur berjalannya proses demokratisasi, karena itu Pemilu harus dilaksanakan secara jujur, adil, langsung, umum, bebas, dan rahasia sesuai dengan kaidah-kaidah universal penyelenggaraan Pemilu yang demokratis. ${ }^{2}$ Pelanggaranhlm. 10.

${ }^{1}$ Sudi Fahmi, Hukum \& Penyelenggaraan Pemerintahan di Indonesia, (Yogyakarta: Total Media, 2012), 
pelanggaran yang terjadi dalam proses penyelenggaraaan Pemilu dalam konteks seperti Pilkada ${ }^{3}$ tentu mempengaruhi kualitas demokrasi, dan pada akhirnya mempengaruhi kualitas calon terpilih. ${ }^{4}$ Biaya yang besar dipersiapkan oleh Negara untuk Pilkada menjadi terbuang sia-sia dan sehingga tujuan dari Pemilu tercapai.

Penyelenggaraan Pemilu merupakan suatu pemenuhan hak-hak politik dari masyarakat. ${ }^{5}$ Penyelenggaraan Pemilu tidak bisa terpisahkan dengan penyelenggaranya, berdasarkan Undang-Undang Nomor 15 Tahun 2011 tentang Penyelenggara Pemilu, yang menjadi penyelenggara Pemilu terdiri atas Komisi Pemilihan Umum, Badan Pengawas Pemilu dan Dewan Kehormatan Penyelenggara Pemilu (DKPP) sebagai satu kesatuan fungsi penyelenggaraan Pemilu dan Indonesia merupakan satu-satunya negara di dunia yang punya lembaga Pemilu ada tiga. ${ }^{6}$

Posisi yang strategis sebagai penyelenggara Pemilu, memiliki potensi penyimpangan tingkah dan laku sebagai penyelenggara. Banyaknya pengaduan etik yang sampai ke DKPP menjadi sorotan publik terhadap penyelenggara Pemilu yang independen dan tidak memihak.

Pedoman etik yang menjadi acuan, berupa Peraturan Bersama KPU, BAWASLU, DKPP Nomor 13, Nomor 11 dan Nomor 1 Tahun 2012 tentang Kode Etik Penyelenggara Pemilihan Umum yang merupakan norma mengenai etik penyelenggara Pemilu.
Ketentuan etik ini ada demi tercapainya Pemilu yang berkualitas dan menjaga independesi penyelenggara Pemilu. Fakta yang ditemukan, banyak penyelenggara Pemilu yang melakukan pelanggaran, berupa pelanggaran administrasi, pelanggaran etik hingga pelanggaran pidana yang dapat mencederai semangat kedaulatan rakyat yang menjadi tujuan dari Pemilu itu sendiri.

Pelanggaran etik penyelenggara Pemilu pernah terjadi di Provinsi Riau khususnya di Kabupaten Rokan Hulu pada tahun 2015 yang lalu. Terkait isu pelanggaran etik penyelenggara Pemilu di Kabupaten Rokan Hulu tersebut maka permasalahan dalam artikel ini ada 2 (dua): Pertama, bagaimana implementasi Peraturan Bersama KPU, BAWASLU dan DKPP di Kabupaten Rokan Hulu Tahun 2015? Kedua, bagaimana penyelesaian pelanggaran Kode Etik Penyelenggara Pemilu di Kabupaten Rokan Hulu Tahun 2015?

\section{Metode Penelitian}

Metode penelitian yang digunakan dalam artikel ini merupakan penelitian hukum sosiologis, yakni dengan lebih memfokuskan terhadap persoalan-persoalan yang muncul. Untuk itu, penulis menitikberatkan pembahasan pada ketentuan perundang-undangan dan melihat hukum dipraktikkan dalam masyarakat, sedangkan sifat penelitian yang digunakan merupakan penelitian lapangan atau field research, yaitu penelitian langsung ke lapangan.

\footnotetext{
${ }^{2}$ Ria Casmi Arrsa, Pemilu Serentak dan Masa Depan Konsolidasi Demokrasi, Jurnal Konstitusi, Volume 11, Nomor 3, September 2014. hlm. 532.

${ }^{3}$ Pengunaan istilah Pemilukada maupun Pilkada mengambarkan, bahwa pemilihan umum tersebut untuk melakukan suksesi kepemimpinan daerah (gubernur, bupati dan walikota).

${ }^{4}$ Janedri M. Gaffar, Politik Hukum Pemilu, (Jakarta: Konstitusi Press, 2012), hlm. 87. hlm. 76.

${ }^{5}$ Emilda Firdaus dan Nabella Puspa Rani, Hukum Tata Negara, (Yogyakarta: Genta Publishing, 2015),

${ }^{6}$ Jimly Asshiddiqie, Peradilan Etik dan Etika Konstitusi, (Jakarta: Sinar Grafika, 2015). hlm. 275.
} 
Lokasi penelitian dalam artikel ini pada wilayah penyelenggaraan pemilihan umum di Provinsi Riau, sedangkan populasi penelitian terdiri dari Komisi Pemilihan Umum (KPU) Provinsi Riau dan Badan Pengawas Pemilu (BAWASLU) Provinsi Riau. Sampel diperoleh dari populasi yang telah teridentifikasi, penetapan sampel ini menggunakan metode sensus untuk Komisioner KPU Provinsi Riau dan BAWASLU Provinsi Riau.

Jenis data yang digunakan berupa data primer diperoleh melalui responden atau sampel, data ini dapat berasal dari Komisioner KPU dan Komisioner BAWASLU Provinsi Riau yang terpenting permasalahan berhubungan dengan pokok masalah yang dibahas. Data sekunder, yaitu data yang diperoleh dari literatur yang mendukung, serta data tersier sebagai pelengkap.

\section{Tinjauan Pustaka}

Pemilik kekuasaan tertinggi yang sesungguhnya dalam negara Indonesia adalah rakyat. Kekuasaan itu harus disadari berasal dari rakyat, oleh rakyat dan untuk rakyat. Bahkan kekuasaan hendaklah diselenggarakan bersama-sama dengan rakyat. ${ }^{7}$ Kekuasaan tersebutlah yang dijaga dalam pelaksanaan Pemilu, hak-hak konstitusional warga negara tersebut yang tidak boleh dicederai dengan keberpihakan penyelenggara kepada salah satu peserta Pemilu.

Pemilu dalam perspektif politics ethics sejatinya dipahami sebagai sarana di mana terjadinya transformasi etika terapan yang bersifat etis dan aktual yang secara langsung berimplikasi pada perbaikan moralitas berbangsa. Proses penyelenggaraan Pemilu harus mampu menautkan antara etika teoretis dan etika terapan sebagai perwujudan dari implementasi etika terapan. Pemilu merupakan salah satu metode penyaluran aspirasi rakyat. Salah satu cermin negara demokrasi adalah pemerintah yang menjalankan sistem Pemilu dengan baik. Setiap pemerintahan yang mengaku demokratis hendaknya mampu menyelenggarakan Pemilu secara demokratis merupakan pilar penting dalam sistem demokrasi modern.

Pemilu yang beretika merupakan suatu keniscayaan yang patut diresapi oleh semua pemangku kepentingan (stakeholders). Praktik kerja sama terselubung antara penyelenggara dengan peserta Pemilu kerap muncul sehingga yang ditemukan terkadang proses pengambilan kebijakan kelembagaan penyelenggara selalu terbelah. Hal ini lebih banyak disebabkan oleh ketidaknetralan atau ada kepentingan politik untuk memihak calon peserta tertentu.

Rumusan kode etik Penyelenggara Pemilu (Peraturan Bersama KPU, BAWASLU dan DKPP cukup jelas dan konkret. Secara eksplisit jelas, namun sebagian secara implisit terlihat abstrak sehingga dalam tataran implementasi butuh sikap hati-hati. Karena pelanggaran Pemilu baik dalam bentuk pelanggaran administrasi dan pelanggaran tindak pidana Pemilu berpotensi pada pelanggaran kode etik. Pembenahan etika kehidupan berbangsa yang dimulai dengan membenahi etika di bidang politik. Pembenahan etika di bidang politik secara otomatis melebar ke etika pemilu dan etika pemilu dimulai dengan pembenahan penyelenggara pemilu. Karena bila penyelenggaraan bisa diperbaiki maka yang lainnya secara bertahap akan menuju perbaikan pula. Penyelenggaraan Pemilu berbasis aturan dan mekanisme serta bagaimana memastikan adanya proses transformasi nilai politik yang berorientasi pada moral.

${ }^{7}$ Jimly Asshiddiqie, Konstitusi \& Konstitusionalisme Indonesia, (Jakarta: Sinar Grafika, 2012). hlm. 58. 
Menurut Frans Magnis Suseno etika adalah suatu ilmu yang membahas tentang bagaimana dan mengapa mengikuti suatu ajaran moral tentu atau bagaimana mengambil sikap yang bertanggung jawab berhadapan dengan berbagai ajaran moral. Etika dibagi dalam dua bentuk:

1. Bersifat umum, adalah prinsip-prinsip yang berlaku bagi setiap tindakan manusia.

2. Bersifat khusus, dibagi lagi menjadi etika individu yang menerangkan tentang bagaimana kewajiban manusia terhadap dirinya sendiri.

Pemilu merupakan salah satu syarat demokrasi, sebab dengan Pemilu dapat dibentuk "pemerintahan dari rakyat, oleh rakyat dan untuk rakyat". Melalui Pemilu tersedia ruang bagi setiap warga negara untuk berkompetisi menduduki jabatan pemerintahan secara fair atas pilihan warga negara. Dengan demikian, Pemilu merupakan mekanisme terpenting bagi keberlangsungan demokrasi perwakilan agar rakyat berdaulat atas dirinya sendiri. Karena itu, Pemilu menjadi indikator negara demokrasi, sehingga tidak ada satu pun negara yang mengklaim dirinya demokratis tanpa melaksanakan Pemilu. ${ }^{8}$

Berdasarkan penelitian yang dilakukan oleh Rudi dan Charlyna Purba bahwa pelanggaran yang dilakukan oleh penyelenggara Pilkada dalam hal administratif biasanya disebabkan karena masalah internal penyelenggara Pilkada, baik dalam hal penetapan jadwal dan tahapan pelaksanaan pemungutan suara maupun inkonsistensi penyelenggara Pilkada dalam menetapkan keabsahan surat suara serta diloloskannya pasangan calon peserta Pilkada yang tidak memenuhi syarat kesehatan berdasarkan hasil pemeriksaan kesehatan menyeluruh dari tim dokter. ${ }^{9}$ Hasil penelitian Rudi dan Charlyna Purba menyebutkan salah satu perkara yang ditanggani oleh Mahkamah Konstitusi dalam sengketa pemilu disebabkan oleh penyelenggara Pemilu.

Berdasarkan penelitian yang dilakukan oleh M. Lutfi Chakim banyak anggota penyelenggara Pemilu yang terbukti melanggar etika dengan bersikap dan bertindak tidak profesional dalam menjalankan tugas dan fungsinya. Oleh karena itu, penegakan kode etik sangat penting sebagai alat kontrol terhadap pelaksanaan nilai-nilai luhur yang dimuat di dalam aturan kode etik, sekaligus menindak tegas setiap perilaku yang terbukti melanggar kode etik. ${ }^{10}$ Peneliti meneliti secara umum perkara-perkara yang ditangani oleh DKPP.

Pengawasan terhadap penyelenggara negara merupakan conditio sine qua non di negara demokrasi. Di samping itu, terdapat beberapa kecenderungan empirik yang membuat keberadaan Mahkamah Etik bagi penyelenggara negara (di Indonesia) juga amat penting. ${ }^{11}$ Mahkamah etik ini yang dipraktikkan oleh DKPP dalam penyelesaian pelanggaran etik oleh penyelenggara Pemilu.

${ }^{8}$ Didik Supriyanto (Editor), Lia Wulandari, Armanda Pransiska, dan Catherine Natalia, Dana Kampanye Pilkada, (Jakarta: Yayasan Perludem, 2015), hlm. 29.

${ }^{9}$ Rudi dan Charlyna Purba, Karakteristik Sengketa Pemilukada di Indonesia Evaluasi 5 Tahun Kewenangan MK Memutus Sengketa Pemilukada, Jurnal Konstitusi, Volume 11, Nomor 1, Maret 2014, hlm. 209.

${ }^{10} \mathrm{M}$. Lutfi Chakim, Desain Institusional Dewan Kehormatan Penyelenggara Pemilu (DKPP) Sebagai Peradilan Etik, Jurnal Konstitusi, Volume 11, Nomor 2, Juni 2014, hlm. 402.

${ }^{11 Z}$ Zulfikri Suleman, Mahkamah Etik Penyelenggara Negara di Negara Demokrasi, Jurnal Etika \& Pemilu, Edisi 1, Mei 2015, hlm. 15. 


\section{Pembahasan}

Implementasi Peraturan Bersama KPU, BAWASLU dan DKPP di Kabupaten Rokan Hulu Tahun 2015

Peraturan Bersama KPU, BAWASLU dan DKPP Nomor 13 Tahun 2012, Nomor 11 Tahun 2012, dan Nomor 1 Tahun 2012 tentang Kode Etik Penyelenggara Pemilu, mengenai tafsir maupun makna yang terdapat di dalam peraturan bersama ini memiliki 2 (dua) pandangan, sebagai berikut:

1. Pandangan yang menyimpulkan ketentuan yang diatur dalam Peraturan Bersama KPU, BAWASLU dan DKPP sudah cukup jelas. Hal ini, menurut penyelenggara pemilu (KPU dan BAWASLU) bahwa apa yang telah diatur berkaitan ketentuan etik sudah cukup jelas dan sudah cukup mengakomodir upaya penegakan etik bagi penyelenggara Pemilu. Kode etik yang telah disepakati 3 (tiga) lembaga dijelaskan dalam Pasal 2 Ayat (2) bersifat mengikat dan wajib dipatuhi oleh Penyelenggara Pemilu semua tingkatan. Peraturan Bersama KPU, BAWASLU dan DKPP, pada prinsipnya menekankan ketaatan terhadap sumpah dan janji penyelenggara Pemilu, juga ketaatan terhadap asas penyelenggara Pemilu. Penegakan kode etik telah mampu menjaga kemandirian, integritas, dan kredibilitas Penyelenggara Pemilu sebagaimana tujuan kode etik dilaksanakan. BAWASLU Provinsi Riau melakukan pengawasan terhadap pelaksanaan Pemilihan Gubernur dan Wakil Gubernur Provinsi Riau tahun 2013,
Pemilihan anggota DPR, DPD dan DPRD tahun 2014, serta pengawasan terhadap pemilihan Presiden dan Wakil Presiden tahun 2014. Dalam proses pengawasan tersebut temuan dugaan pelanggaran kode etik penyelenggara Pemilu diproses dan menghadapi persidangan kode etik yang dilaporkan peserta Pemilu di DKPP Republik Indonesia.

2. Pandangan yang menyatakan bahwa ketentuan etik yang diatur dalam Peraturan Bersama KPU, BAWASLU dan DKPP mengandung multi tafsir dan masih bersifat umum. Pandangan yang menyatakan bahwa masih umumnya dan multi tafsir Peraturan Bersama tentang etik penyelenggara pemilu dinilai masih terlalu umum. ${ }^{12}$ Karena ketentuan yang dijelaskan dalam peraturan bersama tersebut dapat mengandung artian yang multi tafsir. Permasalahan etik menjadi masalah yang baru dalam penyelenggaraan Pemilu. Sebagai proses suksesi kepemimpinan politik maka Pemilu di ranah legislatif maupun eksekutif rentan dengan penyalahgunaan kewenangan oleh penyelenggaranya.

Para Komisioner KPU dan BAWASLU dituntut untuk patuh dan taat dengan ketentuan etik yang melekat pada profesinya sebagai penyelenggara Pemilu. Setiap pelanggaran etik penyelenggara Pemilu diselesaikan dengan mekanisme etik di Dewan Kehormatan Penyelenggara Pemilu (DKPP). Masalah etik yang selalu timbul, ketika hasil pemilu diumumkan oleh KPU menjadi salah satu faktor

\footnotetext{
${ }^{12}$ Hasil wawancara dengan Komisioner KPU Riau, Ilham, S.H., L.LM.
} 
mengapa sering didapati penggaduan ke DKPP, yakni rasa ketidakpuasan peserta Pemilu dengan diumumkannya hasil Pemilu, padahal putusan sidang DKPP tidak mengubah hasil Pemilu, karena ketentuan perundang-undangan menentukan bahwa sengketa hasil Pemilu hanya dapat diselesaikan di Mahkamah Konstitusi. ${ }^{13}$

Berdasarkan Pasal 24C Ayat (1) UndangUndang Dasar Tahun 1945, yang berbunyi sebagai berikut:

"Mahkamah Konstitusi berwenang mengadili pada tingkat pertama dan terakhir yang putusannya bersifat final untuk menguji Undang-Undang terhadap Undang-Undang Dasar, memutus sengketa kewenangan lembaga negara yang kewenangannya diberikan oleh Undang-Undang Dasar, memutus pembubaran partai politik, dan memutus perselisihan tentang hasil pemilihan umum".

Penyelenggara Pemilu dituntut untuk taat dan patuh dengan ketentuan perundangundangan yang berlaku maupun ketentuan etik yang melekat pada profesinya. Ketentuan etik yang begitu umum, menyebabkan tafsiran yang luas bagi yang ingin menggunakan ketentuan etik tersebut. Misalkan dalam kasus dugaan pelanggaran etik oleh komisioner KPU Pusat, Hadar Nafis Gumai yang dilaporkan bertemu dengan salah satu tim sukses presiden, dari hasil pemeriksaan DKPP tidak terbukti melakukan pelanggaran etik, namun isu yang berkembang di masyarakat diduga komisioner KPU tidak independen dalam penyelenggaraan pemilu presiden dan wakil presiden tahun 2014 tidak dapat tertahan, ditambah lagi dengan kekuatan sosial media (medsos) yang bisa mengiring opini masyarakat.
Perilaku maupun tindakan Komisioner KPU dapat dijadikan bahan pelaporan ke DKPP, namun terkadang yang dirasakan oleh Komisioner KPU bahwa sangat begitu luas tafsiran yang terdapat peraturan bersama KPU, BAWASLU dan DKPP, ketentuan yang ada dalam peraturan bersama. Selain memberikan tafsir yang luas, aturan ini juga memberikan kesempatan yang luas bagi penyelenggara Pemilu yang dilaporkan untuk menjawab maupun membuktikan ketidakterlibatan atau sanggahan terhadap pelanggaran etik yang dilaporkan. Hal ini salah satunya terbukti dengan direhabilitasinya nama Komisioner KPU Provinsi Riau yang dilaporkan menerima gratifikasi, hasil pemeriksaan dan putusan DKPP membuktikan bahwa tidak terjadi pelanggaran etik dan direhabilitasi nama baik para komisioner yang dilaporkan.

Dalam konteks rehabilitasi nama, dijumpai bahwa terkadang media tidak terlalu mempublikasikan hasil dari putusan DKPP, hal ini terlihat dalam putusan DKPP terhadap Hadar Nafis Gumay yang tidak terlalu diberitakan oleh media baik cetak maupun elektronik, bisa saja hal ini tidak menjadi prioritas dibanding isu lain yang menjadi perhatian semua media disaat itu.

Menurut Pasal 1 Ayat (1) Peraturan Bersama KPU, BAWASLU dan DKPP No. 13 Tahun 2012, No. 11 Tahun 2012, No. 1 Tahun 2012 tentang Kode Etik Penyelenggara Pemilu, yang memberikan defenisi Pemilu adalah sarana pelaksanaan kedaulatan rakyat yang diselenggarakan secara langsung, umum, bebas, rahasia, jujur dan adil dalam Negara Kesatuan Republik Indonesia berdasarkan Pancasila dan Undang-Undang Dasar Negara Republik Indonesia Tahun 1945.

\footnotetext{
${ }^{13}$ /bid.
} 
Penyelenggara Pemilu adalah lembaga yang menyelenggarakan Pemilu yang terdiri atas KPU dan BAWASLU sebagai satu kesatuan fungsi penyelenggaraan Pemilu untuk memilih anggota Dewan Perwakilan Rakyat, Dewan Perwakilan Daerah, Dewan Perwakilan Rakyat Daerah, Presiden dan Wakil Presiden secara langsung oleh rakyat, serta untuk memilih Gubernur, Bupati dan Walikota secara demokratis. (Pasal 1 Ayat (5) Peraturan Bersama KPU, BAWASLU dan DKPP).

Penyelenggara Pemilu dikawal dan diatur berkenaan etik dalam sebuah peraturan etik berupa kode etik, sedangkan defenisi kode etik penyelenggara Pemilu merupakan satu kesatuan landasan norma moral, etis dan filosofis yang menjadi pedoman bagi perilaku penyelenggara Pemilu yang diwajibkan, dilarang, patut atau tidak patut dilakukan dalam semua tindakan dan ucapan. (Pasal 1 Ayat (6) Peraturan Bersama KPU, BAWASLU dan DKPP) lembaga yang bertugas menanggani pelanggaran kode etik penyelenggara Pemilu berupa DKPP. Kode etik penyelenggara Pemilu ini bersifat mengikat serta wajib dipatuhi oleh penyelenggara Pemilu.

Berdasarkan Pasal 2 Ayat (1), Kode etik Penyelenggara Pemilu berlandaskan pada:

a. Pancasila dan Undang-Undang Dasar Negara Republik Indonesia Tahun 1945.

b. Ketetapan Majelis Permusyawaratan Rakyat dan Undang-Undang.

c. Sumpah/janji jabatan sebagai Penyelenggara Pemilu.

d. Asas Penyelenggara Pemilu.

Tujuan kode etik penyelenggara Pemilu untuk menjaga kemandirian, integritas, dan kredibilitas anggota KPU, anggota KPU Provinsi atau KIP Aceh, anggota KPU Kabupaten/Kota atau KIP Kabupaten/Kota, PPK, PPS, KPPS, PPLN, dan KPPSLN, serta anggota BAWASLU,
Anggota BAWASLU Provinsi, anggota Panwaslu Kabupaten/Kota, anggota Panwaslu Kecamatan, anggota Pengawas Pemilu Lapangan, dan anggota Pengawas Pemilu Luar Negeri.

Penyelenggara Pemilu dalam fungsinya harus dapat menjaga integritas yang pada akhirnya akan meningkatkan percayaan publik terhadap penyelenggara pemilu itu sendiri. Kredibilitas akan menjaga kualitas Pemilu, dana Pemilu yang besar mesti digunakan tepat pada peruntukannya oleh penyelenggara yang memiliki kemampuan dalam menggelolahnya.

Dalam Penyelenggara Pemilu, penyelenggara berpedoman pada asas-asas, antara lain:

a. Mandiri;

b. Jujur;

c. Adil;

d. Kepastian hukum;

e. Tertib;

f. Kepentingan umum;

g. Keterbukaan;

h. Proporsionalitas;

i. Profesionalitas;

j. Akuntabilitas;

k. Efisiensi; dan

I. Efektivitas.

Hal ini sebagaimana diatur dalam Pasal 5. Asas-asas inilah yang dapat mengawal penyelenggara Pemilu tetap berada pada arah yang benar dan tidak terlibat pelanggaran etik bahkan pelanggaran hukum. Penyelenggara Pemilu memiliki kewajiban yang melekat pada setiap diri penyelanggara Pemilu, antara lain:

a. Menjunjung tinggi Pancasila, UndangUndang Dasar Negara Republik Indonesia Tahun 1945, dan peraturan perundang-undangan.

b. Menjunjung tinggi kepentingan bangsa dan Negara Kesatuan Republik Indonesia. 
c. Menunjukkan penghargaan dan kerja sama dengan seluruh lembaga dan aparatur negara untuk kepentingan bangsa dan Negara Kesatuan Republik Indonesia.

d. Menjaga dan memelihara nama baik Negara Kesatuan Republik Indonesia.

e. Memelihara dan menjaga kehormatan lembaga penyelenggara Pemilu.

f. Menjalankan tugas sesuai visi, misi, tujuan, dan program lembaga Penyelenggara Pemilu.

g. Menjaga rahasia yang dipercayakan kepadanya, termasuk hasil rapat yang dinyatakan sebagai rahasia sampai batas waktu yang telah ditentukan atau sampai masalah tersebut sudah dinyatakan untuk umum sepanjang tidak bertentangan dengan peraturan perundang-undangan.

h. Menghargai dan menghormati sesama lembaga penyelenggara Pemilu dan pemangku kepentingan Pemilu.

i. Melakukan segala upaya yang dibenarkan etika sepanjang tidak bertentangan dengan perundangundangan sehingga memungkinkan bagi setiap penduduk yang berhak memilih terdaftar sebagai pemilih dan dapat menggunakan hak memilihnya.

j. Menjaga dan memelihara tertib sosial dalam penyelenggaraan Pemilu.

k. Mengindahkan norma dalam penyelenggaraan Pemilu.

I. Menghormati kebhinnekaan masyarakat Indonesia.

m. Beriman dan bertaqwa kepada Tuhan Yang Maha Esa.

n. Menjunjung tinggi sumpah/janji jabatan dalam melaksanakan tugas, wewenang, kewajiban, dan tanggung jawabnya. o. Menjaga dan memelihara netralitas, imparsialitas, dan asas-asas penyelenggaraan Pemilu yang jujur, adil, dan demokratis.

p. Tidak mengikutsertakan atau melibatkan kepentingan pribadi maupun keluarga dalam seluruh pelaksanaan tugas, wewenang, dan kewajibannya.

q. Melaksanakan tugas-tugas sesuai jabatan dan kewenangan yang didasarkan pada Undang-Undang Dasar Negara Republik Indonesia Tahun 1945, undang-undang, peraturan perundang-undangan, dan keputusan yang berkaitan dengan penyelenggaraan Pemilu.

r. Mencegah segala bentuk dan jenis penyalahgunaan tugas, wewenang, dan jabatan, baik langsung maupun tidak langsung.

s. Menolak untuk menerima uang, barang, dan/atau jasa atau pemberian lainnya yang apabila dikonversi melebihi standar biaya umum dalam jangka waktu paling lama 3 (tiga) jam, dalam kegiatan tertentu secara langsung maupun tidak langsung dari calon peserta Pemilu, peserta Pemilu, calon anggota DPR dan DPRD, dan tim kampanye.

t. Mencegah atau melarang suami/istri, anak, dan setiap individu yang memiliki pertalian darah/semenda sampai derajat ketiga atau hubungan suami/istri yang sudah bercerai di bawah pengaruh, petunjuk, atau kewenangan yang bersangkutan, untuk meminta atau menerima janji, hadiah, hibah, pemberian, penghargaan, dan pinjaman atau bantuan apapun dari pihak yang berkepentingan dengan penyelenggaraan Pemilu. 
u. Menyatakan secara terbuka dalam rapat apabila memiliki hubungan keluarga atau sanak saudara dengan calon, peserta Pemilu, atau tim kampanye.

Kewajiban-kewajiban di atas walaupun aturannya masih terlihat umum, mestilah dibuat aturan teknis yang dapat mengawalnya, terkadang pengaduan yang sampai ke BAWASLU sebelum ditindaklanjuti oleh DKPP, ditemukan bahwa penyelenggara Pemilu di tingkat kabupaten bahkan kecamatan masih lemah tentang pemahaman ketentuan etik.

Berdasarkan ketentuan beracara dalam perkara pelanggaran etik, yang dapat menjadi pengadu dalam pelanggaran kode etik pemilu, antara lain:

a. Penyelenggara Pemilu;

b. Peserta Pemilu;

c. Tim kampanye;

d. Masyarakat; dan/atau

e. Pemilih.

Pengaduan dan/atau Laporan dugaan pelanggaraan kode etik disampaikan secara tertulis dalam Bahasa Indonesia sebanyak 8 (delapan) rangkap yang memuat, sebagai berikut:
a. Identitas lengkap pengadu dan/atau pelapor.
b. Identitas teradu dan/atau terlapor.
c. Alasan pengaduan dan/atau laporan. dan memeriksa dan memutus dugaan pelanggaran kode etik.
d. Permintaan kepada DKPP untuk
Identitas teradu dan/atau terlapor paling sedikit memuat, sebagai berikut:

a. Nama lengkap; b. Jabatan; dan

c. Alamat kantor.

Alasan pengaduan dan/atau Laporan memuat uraian jelas mengenai tindakan atau sikap teradu dan/atau terlapor yang meliputi:
a. Waktu perbuatan dilakukan;
b. Tempat perbuatan dilakukan;
c. Perbuatan yang dilakukan; dan
d. Cara perbuatan dilakukan.

Kaidah etik ditegakkan oleh Dewan Kehormatan yang rekomendasinya wajib diresmikan dan dilaksanakan oleh KPU. Sanksi bagi unsur penyelenggara Pemilu yang terbukti melanggar kaidah tersebut berkisar dari peringatan tertulis sampai dengan pemecatan dengan tidak hormat. Pelanggaran kode etik penyelenggara Pemilu. ${ }^{14}$

Pelanggaran kode etik adalah pelanggaran terhadap prinsip-prinsip moral dan etika penyelenggara Pemilu yang berpedoman kepada sumpah/janji sebelum menjalankan tugas sebagai penyelenggara Pemilu dan asas penyelenggara Pemilu yang diberlakukan, ditetapkan oleh KPU. Maksud kode etik adalah untuk menjaga kemandirian, integritas, akuntabilitas, dan kredibilitas penyelenggara Pemilu, sedangkan tujuan kode etik adalah memastikan terselenggaranya Pemilu secara langsung, umum, bebas, rahasia, jujur dan adil. $^{15}$

Berdasarkan Putusan Nomor 111/DKPPPKE-V/2016 DKPP Pemilu Republik Indonesia yang sebelumnya menerima Pengaduan Nomor 155/V-P/LDKPP/2015, dan diregistrasi pada tanggal 21 Juni 2016 yang disiarkan secara teleconference Kantor BAWASLU Provinsi Riau. Terdapat beberapa jenis

\footnotetext{
${ }^{14}$ Ramlan Surbakti, Ketentuan Administrasi Pemilu: Mekanisme Pengaduan dan Penegakannya, Jurnal Pemilu dan Demokrasi. Volume 1 Desember 2011. hlm. 1.

${ }^{15}$ Topo Santoso. Penguatan Penegakan Hukum Pemilu, Jurnal Pemilu dan Demokrasi. Volume 2 Februari 2012. HIm. 90.
} 
pelanggaran etik yang dilakukan oleh terlapor (Rahmat Kurniawan, S.E.), sebagai berikut:

1. Teradu menandatangani beberapa Surat KPU Kabupaten Rokan Hulu, mengatasnamakan Ketua KPU Kabupaten Rokan Hulu. Teradu menandatangani surat perjanjian peminjaman kendaraan dinas KPU Kabupaten Rokan Hulu dengan Sekda Kabupaten Rokan Hulu. Dalam sidang pemeriksaan terungkap fakta bahwa teradu juga menandatangani surat perjanjian KPU Kabupaten Rokan Hulu dengan pimpinan Toko Star Auto Mobil dalam hal pembelian alat-alat kendaraan dan service kendaraan dinas roda empat. Terkait dengan hal tersebut, DKPP berpendapat teradu dalam menandatangani surat KPU Kabupaten Rokan Hulu dengan mengatasnamakan Ketua KPU Kabupaten Rokan Hulu, tidak memiliki kapasitas dan legal standing. Teradu yang terpilih sebagai Ketua KPU Kabupaten Rokan Hulu menggantikan Fahrizal, S.T., M.T. melalui voting dalam pleno Komisioner KPU Kabupaten Rokan Hulu, tidak sah secara hukum. Meskipun secara de facto teradu telah terpilih sebagai Ketua KPU Kabupaten Rokan Hulu, namun secara de jure belum sah karena KPU Provinsi Riau yang secara hierarki sebagai atasan langsung teradu belum mengeluarkan Surat Keputusan (SK) sebagai dasar hukum yang memberikan kewenangan pengangkatan teradu sebagai Ketua KPU Kabupaten Rokan Hulu menggantikan Fahrizal. DKPP berpendapat, teradu seharusnya tidak menandatangani atau mengatasnamakan sebagai Ketua KPU Kabupaten Rokan Hulu sebelum terbit
Surat Keputusan (SK) pengangkatan teradu. Berdasarkan fakta tersebut, teradu terbukti melakukan pelanggaran kode etik penyelenggara Pemilu. Teradu terbukti melakukan tindakan dalam rangka penyelenggaraan Pemilu yang tidak sesuai prosedur dan yurisdiksinya, sesuai dengan ketentuan Pasal 11 Huruf b dan c, Pasal 15 huruf b Peraturan Bersama KPU, BAWASLU, dan DKPP Nomor 13 Tahun 2012, Nomor 11 Tahun 2012, dan Nomor 1 Tahun 2012 tentang Kode Etik Penyelenggara Pemilu.

2. Terkait dengan uang sebesar $\mathrm{Rp}$ 10.642.000,00 (sepuluh juta enam ratus empat puluh dua ribu rupiah) yang diterima teradu melalui Bendahara KPU Kabupaten Rokan Hulu atas nama Kamaruddin dipergunakan teradu untuk kepentingan pribadi. Hal ini diakui oleh teradu dalam sidang pemeriksaan yang dilaksanakan DKPP di BAWASLU Provinsi Riau. Terungkap fakta dalam persidangan uang tersebut yang seharusnya membayar pembelian alatalat dan service kendaraan dinas roda empat kepada Star Auto Mobil tidak dibayarkan oleh teradu. KPU Kabupaten Rokan Hulu harus mengeluarkan kembali uang untuk membayarkannya, sebagai konsekuensinya teradu telah mengganti uang tersebut dengan pemotongan gaji yang diterima teradu sebagai Komisioner KPU Kabupaten Rokan Hulu. Berdasarkan fakta tersebut, DKPP berpendapat seharusnya teradu tidak menggunakan uang KPU Kabupaten Rokan Hulu untuk kepentingan pribadi. Hal ini mencoreng instansi KPU Kabupaten Rokan Hulu yang harus menerima tuntutan 
pembayaran tagihan dari Star Auto Mobil.

3. Dalam sidang pemeriksaan, teradu juga mengakui menjadi perantara bagi para pencari kerja dengan cara menawarkan jasa mengurus tenaga honorer di lingkungan Pemerintah Daerah Kabupaten Rokan Hulu dan KPU Kabupaten Rokan Hulu.

4. Teradu juga mengaku memiliki kebiasaan tak terpuji bermain judi bola online. Tindakan tersebut sepatutnya tidak dilakukan oleh teradu sebagai penyelenggara Pemilu dan nyata-nyata telah mencemarkan nama baik kelembagaan penyelenggara Pemilu khususnya KPU Kabupaten Rokan Hulu.

5. Terkait dengan uang gratifikasi sebagaimana dalil aduan para pengadu, terungkap fakta dalam persidangan uang tersebut berasal dari Jalalus selaku Sekretaris Tim Pemenangan Pasangan Calon Bupati dan Wakil Bupati Rokan Hulu Suparman-Sukiman. Hal ini dibenarkan oleh Mario selaku staf honorer Sekretariat KPU Rokan Hulu yang menerima uang tersebut langsung dari Jalalus kemudian menyerahkannya kepada lima Komisioner KPU Kabupaten Rokan Hulu. Dalam sidang pemeriksaan, Mario mengakui pada saat membagikan uang dari Jalalus, hanya teradu yang menerima. Berdasarkan fakta tersebut, DKPP berpendapat tindakan teradu yang menerima gratifikasi dari pasangan calon merupakan pelanggaran etik berat. Teradu terbukti tidak dapat memelihara dan menjaga kehormatan lembaga KPU Kabupaten Rokan Hulu. Teradu terbukti melanggar ketentuan Pasal 7 huruf a, Pasal 9 huruf $\mathrm{g}$, dan Pasal 10 huruf $c$ dan k Peraturan Bersama KPU, BAWASLU, dan DKPP Nomor 13 Tahun 2012, Nomor 11 Tahun 2012, dan Nomor 1 Tahun 2012 tentang Kode Etik Penyelenggara Pemilu. Terkait dengan Staf Sekretariat KPU Kabupaten Rokan Hulu atas nama Mario yang membagikan amplop berisikan uang dari Jalalus, DKPP berpendapat tindakan Mario juga dikategorikan sebagai pelanggaran kode etik berat. Dalam perkara a quo Mario selaku Staf Sekretariat KPU Kabupaten Rokan Hulu tidak diadukan, namun demikian untuk menjaga martabat penyelenggara Pemilu, DKPP berpendapat harus menjatuhkan sanksi kepadanya. DKPP memerintahkan kepada Sekretaris KPU Kabupaten Rokan Hulu untuk melakukan evaluasi, pembinaan, dan penegakan disiplin kepada Mario.

Penyelesaian Pelanggaran Kode Etik Penyelenggara Pemilu di Kabupaten Rokan Hulu Tahun 2015

Dalam kasus pelanggaran etik yang melibatkan Anggota Komisioner KPU Kabupaten Rokan Hulu Provinsi Riau, pengaduan ke DKPP dilakukan oleh KPU Provinsi Riau yang merupakan atasan dari teradu, dari proses supervise ditemukan adanya dugaan pelanggaran etik yang dilakukan oleh teradu. ${ }^{16}$

${ }^{16}$ Hasil wawancara dengan KPU Provinsi Riau, Bapak Ilham, S.H., L.LM pada tanggal 18 November 2016 di Kantor KPU Provinsi Riau. 
Menurut KPU Provinsi Riau, teradu sebelumnya sudah pernah menjalani proses pembinaan yang dilakukan oleh KPU Provinsi Riau, yaitu pada tanggal 13 April 2015, melalui Keputusan Rapat Pleno KPU Provinsi Riau Nomor :19/BA/KPU-Prov-004/Tahun 2015 tentang Teguran Keras kepada Teradu, yang merupakan hasil temuan KPU Provinsi Riau dari hasil proses supervisi terhadap KPU Kabupaten Rokan Hulu, diantaranya pada tanggal 5 Maret 2015 saat menurunkan tim yang terdiri dari Sdr. Drs Syafril Abdullah, M.Si (Korwil/Divisi Logistik), Sdri. Sri Rukmini, S.H., M.IKom (Divisi SDM), Sdr. Kamirin Land, M.Si (Kabag SDM), dan Sdri. Dra $\mathrm{Hj}$. Odeng Rahmadani (Kabag Hukum \& Teknis) menemui Sekretaris Daerah Kabupaten Rokan Hulu dan Ketua DPRD Rokan Hulu untuk berkomunikasi terkait beberapa persoalan di KPU Kabupaten Rokan Hulu menghadapi Pilkada 2015, muncul keinginan dari Pemerintah Daerah yang disampaikan oleh Ketua DPRD dan Sekretaris Daerah Kabupaten Rokan Hulu untuk mengganti Ketua KPU Kabupaten Rokan Hulu Sdr. Fahrizal, S.T., M.T. yang kemudian oleh KPU Provinsi Riau disimpulkan sebagai suatu bentuk intervensi maka selanjutnya diambil langkah-langkah dengan mengundang kembali Anggota KPU Kabupaten Rokan Hulu ke KPU Provinsi Riau, diantaranya tanggal 9 Maret 2015, dan 8 April 2015 yang menemukan ada cacat hukum dalam proses pleno pergantian ketua, dan temuan permasalahan hukum pada diri teradu, yang kemudian dari hasil memeriksa dengan mendengarkan laporan, pengaduan, serta keterangan/pengakuan dari teradu bersama 4 (empat) anggota KPU Rokan Hulu yang lainnya dihadapan 5 (lima) Anggota KPU Provinsi Riau, teradu terbukti serta mengakui telah melakukan pemalsuan tanda tangan atas nama Ketua KPU Rokan Hulu Sdr. Fahrizal, S.T., M.T. atas Surat Keputusan Nomor 031/ Kpts/KPU-Rohul-004.435234///2015, tanggal 2
Januari 2015 tentang Pengangkatan Tenaga Honor Kontrak a.n Irawati, A.Md di lingkungan Sekretariat KPU Kabupaten Rokan Hulu dan Sekretaris KPU Rokan Hulu Sdr. Sariaman atas Surat Keputusan Nomor 263/Kpts/Ses.KPURohul-004.435234///2015, tanggal 2 Januari 2015 tentang Pengangkatan Tenaga Honor Kontrak a.n Riswandi, S.H. di lingkungan Sekretariat KPU Kabupaten Rokan Hulu.

Pada tanggal 6 April 2015 atau 7 hari sebelum mendapatkan proses pembinaan atau setidak-tidaknya pada saat proses sedang dimintai keterangan di Kantor KPU Provinsi Riau, teradu kembali bertindak mengatasnamakan Ketua KPU Rokan Hulu Sdr. Fahrizal, S.T., M.T. dengan melakukan perjanjian peminjaman kendaraan dinas sepihak dengan Sekda Kabupaten Rokan Hulu Sdr. Ir. Damri, padahal belum ada surat keputusan yang dikeluarkan oleh KPU Provinsi Riau sebagai dasar hukum yang memberikan kewenangan pengangkatan teradu sebagai Ketua KPU Kabupaten Rokan Hulu menggantikan Sdr. Fahrizal, S.T., M.T.

Pada tanggal 8 April 2015 atau 5 hari sebelum mendapat proses pembinaan atau setidak-tidaknya pada saat proses dimintai keterangan di Provinsi Riau teradu lagi-lagi kembali melakukan tindakan mengatasnamakan Ketua KPU Rokan Hulu, Sdr. Fahrizal, S.T., M.T. mengetahui dan/atau menyetujui perjanjian Bendahara KPU Kabupaten Rokan Hulu Sdr. Kamaruddin, S.H. dengan Sdr. Budiman Lubis, S.T. pimpinan Toko Star Auto Mobil beralamat di Jalan Tuanku Tambusai, Pasir Pengaraian terkait pembelian alat-alat kendaraan dan service kendaraan dinas roda empat, padahal belum ada surat keputusan yang dikeluarkan oleh KPU Provinsi Riau sebagai dasar hukum yang memberikan kewenangan pengangkatan teradu sebagai Ketua KPU Kabupaten Rokan Hulu menggantikan Sdr. Fahrizal, S.T., M.T. 
Kasus yang menjerat salah satu Komisioner KPU Kabupaten Rokan Hulu, merupakan kasus pelanggaran etik yang masuk dalam kategori berat, karena pelanggaran etik yang dilakukan dapat mengarah kepada pelanggaran pidana. Putusan DKPP hanya punya menyangkut pelanggaran etik, serta sanksi yang diberikan berupa sanksi etik (untuk pelanggaran berat sanksinya berupa pemberhentian sebagai penyelenggara Pemilu).

Pelanggaran-pelanggaran yang dilakukan oleh penyelenggara Pemilu di atas seolah-olah pedoman etik tidak mampu memberikan benteng yang kuat, untuk mencegah tingkah dan laku yang mencederai integritas penyelenggara Pemilu. Solusi untuk meningkatkan status Peraturan Bersama KPU, BAWASLU dan DKPP menjadi setingkat undang-undang mungkin bisa menjadi terobosan hukum dan disertai sanksi yang berat bagi pelanggarnya.

\section{Kesimpulan}

1. Implementasi Peraturan Bersama KPU, BAWASLU dan DKPP di Kabupaten Rokan Hulu telah diterapkan pada kasus konkrit berdasarkan Putusan Nomor 111/DKPPPKE-V/2016 DKPP Pemilu Republik Indonesia yang sebelumnya menerima Pengaduan Nomor 155/V-P/LDKPP/2015, dan diregistrasi pada tanggal 21 Juni 2016 yang disiarkan secara teleconference Kantor BAWASLU Provinsi Riau dengan terlapor (Rahmat Kurniawan, S.E.)

2. Penyelesaian pelanggaran kode etik penyelenggara Pemilu di Kabupaten Rokan Hulu Tahun 2015 yang melibatkan Anggota Komisioner KPU Kabupaten Rokan Hulu Provinsi Riau, merupakan kasus pelanggaran etik yang masuk dalam kategori berat. Putusan DKPP hanya punya menyangkut pelanggaran etik, serta sanksi yang diberikan berupa sanksi etik (untuk pelanggaran berat sanksinya berupa pemberhentian sebagai penyelenggara Pemilu).

\section{Saran}

1. Perlunya sosialisasi tentang ketentuan etik keseluruh penyelenggara Pemilu, KPU maupun BAWASLU sampai tingkat terendah.

b. Perlunya meninjau kembali efektifitas Peraturan Bersama KPU, BAWASLU dan DKPP tentang Kode Etik Penyelenggara Pemilu untuk ditingkatkan statusnya menjadi Undang-Undang dan sanksi tambahan yang dapat membawa efek jera bagi pelanggarnya.

\section{Referensi}

Didik Supriyanto (Editor), Lia Wulandari, Armanda Pransiska, dan Catherine Natalia. 2015. Dana Kampanye Pilkada. Jakarta: Yayasan Perludem.

Emilda Firdaus dan Nabella Puspa Rani. 2015. Hukum Tata Negara. Yogyakarta: Genta Publishing.

Janedri M. Gaffar. 2012. Politik Hukum Pemilu. Jakarta: Konstitusi Press.

Jimly Asshiddiqie. 2010. Konstitusi \& Konstitusionalisme Indonesia. Jakarta: Sinar Grafika.

_—___2015. Peradilan Etik dan Etika Konstitusi. Jakarta: SinarGrafika.

M. Lutfi Chakim. Desain Institusional Dewan Kehormatan Penyelenggara Pemilu (DKPP) Sebagai Peradilan Etik. Jurnal Konstitusi. Volume 11. Nomor 2. Juni 2014.

Ramlan Surbakti. Ketentuan Administrasi Pemilu: Mekanisme Pengaduan dan 
Penegakannya. Jurnal Pemilu dan Demokrasi. Volume 1. Desember 2011.

Ria Casmi Arrsa. Pemilu Serentak dan Masa Depan Konsolidasi Demokrasi. Jurnal Konstitusi. Volume 11. Nomor 3. September 2014.

Rudi dan Charlyna Purba. Karakteristik Sengketa Pemilukada di Indonesia Evaluasi 5 Tahun Kewenangan MK
Memutus Sengketa Pemilukada. Jurnal Konstitusi. Volume 11. Nomor 1. Maret 2014.

Topo Santoso. Penguatan Penegakan Hukum Pemilu. Jurnal Pemilu dan Demokrasi. Volume 2. Februari 2012.

Zulfikri Suleman. Mahkamah Etik Penyelenggara Negara di Negara Demokrasi. Jurnal Etika \& Pemilu. Edisi 1. Mei 2015. 